\title{
Peningkatan Komitmen Tugas Terhadap Kompetensi Pedagogik Guru Melalui Peran Pengawas Sekolah dan Kepala Sekolah di SMA Negeri 7 Kota Tangerang
}

\author{
Hikmat $^{1}$ \\ ${ }^{1}$ Program Pascasarjana Universitas Islam Syekh-Yusuf \\ Email: hikmatachdiat@mail.com
}

\begin{abstract}
Abstrak
Penelitian Tindakan Sekolah ini mempunyai tujuan untuk meningkatkan kompetensi pedagogik guru melalui peran pengawas dan kepala sekolah di SMA Negeri 7 Kota Tangerang. Penelitian Tindakan Sekolah ini terdiri dari 2 siklus, dan tiap siklus terdiri dari 4 tahapan yaitu perencanaan, pelaksanaan, observasi dan refleksi. Adapun indikator keberhasilan adalah penelitian ini dikatakan berhasil jika terjadi peningkatan hasil skor ratarata komitmen tugas minimal $80 \%$ dengan kategori tinggi dan kompetensi pedagogik minimal $65 \%$ guru rata-rata mencapai kriteria amat baik. Hasil penelitian menunjukkan bahwa: 1) terjadi komitmen tugas dengan nilai rata-rata 74,41 termasuk pada kategori sedang pada siklus pertama dan pada siklus kedua mencapai nilai rata-rata 81,93 termasuk pada kategori tinggi. 2) Aktivitas guru dalam mengikuti workshop penyusunan RPP yang lengkap dan Kompetensi pedagogik guru dengan nilai rata-rata $65,4 \%$ yaitu 11 orang atau $22 \%$ guru dengan kriteria amat baik, 32 orang atau $64 \%$ dengan kategori baik dan 7 orang atau $14 \%$ dengan kategori cukup pada siklus pertama dan meningkat pada siklus kedua mencapai nilai rata-rata $73,2 \%$ dengan 35 orang atau $70 \%$ guru dengan kriteria amat baik, 15 orang atau $30 \%$ dengan kategori baik. Berdasarkan hasil penelitian ini penulis memberikan saran kepada guru SMA Negeri 7 Kota Tangerang agar dapat melibatkan diri dalam kegiatan MGMP sehingga dapat meningkatkan kompetensi pedagogik guru dalam mengajar di kelas dan untuk kepala sekolah agar memfasilitasi guru yang jadi bawahannya untuk aktif dalam kegiatan MGMP guna meningkatkan kompetensi pedagogiknya.
\end{abstract}

Kata Kunci: Komitmen Tugas, Kompetensi Pedagogik

\section{A. Pendahuluan}

Guru memiliki peran yang sangat penting dalam pendidikan formal dalam rangka meningkatkan kualitas peserta didik. Oleh karena itu diperlukan guru profesional untuk mendukung peningkatan kualitas pembelajaran di sekolah. Guru sebagai tenaga profesional diharuskan memiliki kompetensi profesional, di samping kompetensi pedagogik, kompetensi kepribadian, dan kompetensi sosial. Tanpa bermaksud mengabaikan salah satu kompetensi yang ada, dalam penelitian ini hanya akan dibahas tentang kompetensi pedagogik guru.

Menurut Marselus R. Payong (2011: 28-29) pedagogik berarti membimbing/mengatur anak. Tugas membimbing ini melekat dalam tugas seorang pendidik, maka guru tidak hanya sebagai pengajar yang mentransfer ilmu pengetahuan dan keterampilan kepada siswa, tetapi juga merupakan pendidik dan pembimbing yang membantu siswa untuk mengembangkan segala potensinya baik itu potensi akademik maupun non akademik. Dalam kegiatan pembelajaran, kompetensi yang dominan harus dimiliki guru adalah kompetensi pedagogik. Kompetensi ini merupakan rambu-rambu yang harus dijadikan pedoman guru dalam proses pembelajaran.

Menurut Suharsimi Arikunto (2004: 23), kegiatan pokok pengawas sekolah adalah melakukan pembinaan kepada personil sekolah pada umumnya dan khususnya guru, agar kualitas pembelajarannya meningkat atau sering disebut dengan supervisi. Supervisi diartikan sebagai kegiatan yang dilakukan 
oleh pengawas dan kepala sekolah atau pejabat yang berkedudukan di atas atau lebih tinggi dari guru untuk melihat atau mengawasi petugasan guru. Supervisi bertugas melihat dengan jelas masalahmasalah yang muncul dalam mempengaruhi situasi belajar dan menstimulir guru ke arah usaha perbaikan.

Konskuensi logis bahwa seorang guru harus siap disupervisi setiap saat, karena adanya pengawas sekolah akan mampu meningkatkan kompetensi pedagogik guru. Mengingat, di SMA Negeri 7 Kota Tangerang belum sepenuhnya supervisi dilaksanakan secara terjadwal dan periodik, sehingga hasil yang dicapai dari kegiatan ini belum tepat sasaran. Guru membutuhkan pengawas sekolah yang bersifat kunjungan kelas, sehingga guru bisa mendapatkan masukan mengenai cara mengajarnya apakah sudah baik atau masih ada beberapa hal yang perlu ditingkatkan. Selain itu, supervisi tersebut dilakukan untuk mengetahui kesesuaian pembelajaran dengan kurikulum yang sedang diterapkan saat ini. Salah satu bentuk langkah perbaikan pembelajaran adalah adanya peran pengawas sekolah dengan melakukan supervisi akademik.

Peran kepala sekolah adalah membantu guru memahami isu-isu dan membuat keputusan yang bijak yang dapat mempengaruhi pendidikan peserta didik secara positif. Dalam hal ini kepala sekolah berperan sebagai mitra, innovator dan pelopor, konsultan, dan motivator. Salah satu peran kepala sekolah diantaranya sebagai motivator. Kepala sekolah harus memiliki strategi yang tepat untuk memberikan motivasi kepada tenaga kependidikan dalam melaksanakan tugas dan fungsinya. Hal tersebut dikarenakan motivasi merupakan faktor yang dominan dan dapat menggerakkan faktor-faktor lain ke arah efektifitas tugas. Pentingnya peran kepala sekolah dilakukan agar kepala sekolah dapat lebih memahami tugas dan kewajibannya secara mendalam. Hal ini sejalan dengan penelitian Fred C.
Lunenburg (2013) menemukan bahwa sekolah yang efektif memiliki kepala sekolah yang menunjukkan kepemimpinan kurikulum instruksional yang kuat serta keterampilan manajemen esensial.

Selain peran pengawas sekolah dan peran kepala sekolah, komitmen tugas guru juga merupakan salah satu faktor yang dapat mempengaruhi kompetensi pedagogik guru disekolah dasar. Komitmen guru merupakan salah satu bentuk pelaksanaan tanggung jawabnya sebagai seorang guru. Komitmen guru merupakan penafsiran internal seorang guru tentang bagaimana mereka menyerap dan memaknai pengalaman tugas mereka (Solomon, 2007: 14). Komitmen guru dalam menjalankan tugas berperan penting dalam peningkatan kompetensi pedagogik . Komitmen ini meliputi, aspek komitmen pada lembaga, pada petugasan, pada kedudukan, komitmen pada kelompok tugas. Guru yang memiliki komitmen kuat akanbetugas ekstra, dengan menggunakann kompetensi, waktu, tenaga, pikiran dan pengorbanan melebihi dari standar normal aturan main dalam sekolah.Guru mendapatkan penghargaan karena prestasi bagus dan hukuman bagi yang melanggar aturan main tentu menjadi notivasi tersendiri untuk menghasilkan kinerja yang baik bagi guru.

Kompetensi pedagogik adalah kemampuan mengelola pembelajaran peserta didik yang meliputi pemahaman terhadap peserta didik, perancangan dan pelaksanaan pembelajaran, evaluasi hasil belajar dan pengembangan peserta didik untuk mengaktualisasikan berbagai potensi yang dimilikinya. Oleh karena itu, guru di SMA Negeri 7 Kota Tangerang perlu meningkatkan kualifikasi akademiknya dan dituntut untuk komitmen terhadap profesionalisme dalam mengemban tugasnya.

Seorang guru dikatakan memiliki komitmen tugas guru bila mana pada dirinya melekat sikap dedikasi yang tinggi terhadap tugasnya, sikap komitmen terhadap mutu proses dan hasil tugas, serta 
sikap yang selalu berusaha memperbaiki dan memperbaharui model-model atau cara tugasnya sesuai dengan tuntutan zaman, yang dilandasi oleh kesadaran yang tinggi bahwa tugas mendidik adalah tugas menyiapkan generasi penerus yang akan hidup pada zamannya dimasa depan.

Dari uraian di atas, maka tujuan dalam penelitian ini adalah menkaji peningkatna komitmen tugas terhadap kompetensi pedagogik guru di SMA Negeri 7 Kota Tangerang melalui peran Pengawas Sekolah, dan Kepala Sekolah. Dengan kajian tersebut, maka diharapkan diperoleh informasi untuk memperluas pemahaman Guru Sekolah Menengah Atas tentang peran pengawas sekolah, peran kepala sekolah, dan komitmen tugas guru, juga dapat digunakan sebagai dasar pelaksanaan penelitian-penelitian selanjutnya, untuk mendapatkan hasil yang lebih sempurna dan untuk menambah keilmuan pendidikan.

\section{Kajian Teori \\ Komitmen Tugas Guru}

Komitmen adalah salah satu faktor yang dapat empermudah dan sekaligus memperingan suatu tugas atau petugasan, meskipun bobot atau beban tugas itu dirasakan cukup berat. Apabila seorang guru memiliki komitmen yang tinggi, berarti guru menjalankan tugas-tugas keprofesiannya dengan situasi psikologis keterlibatan total, antusias, penuh gairah dalam mengajar, fokus pada usaha dan memiliki kekuatan yang besar.

Robbins (2000 : 69) menjelaskan bahwa komitmen tugas guru terhadap organisasi sekolah merupakan sebuah proses berkesinambungan dan merupakan sebuah pengalaman individu ketika bergabung dalam sebuah organisasi sekolah. Komitmen organisasional timbul secara bertahap dalam diri pribadi guru itu sendiri. Berawal dari kebutuhan pribadi terhadap organisasi kemudian beranjak menjadi kebutuhan bersama dan rasa memiliki dari para guru terhadap organisasi sekolah. Wursanto (2010: 15) mengemukakan bahwa rasa memiliki dari para guru dapat dilihat dari adanya loyalitas dari para guru terhadap guru lainnya, loyalitas para guru terhadap sekolah, kesediaan berkorban secara ikhlas dari para guru baik moril maupun material demi kemajuan sekolahnya, adanya rasa bangga dari para guru apabila sekolah tersebut mendapat nama baik dari masyarakat, adanya niat baik (good will) dari para guru untuk tetap menjaga nama baik sekolahnya dalam keadaan apapun.

Wursanto (2010: 16) mengemukakan kesepakatan bersama yang merupakan komitmen dari guru itu meliputi tujuan yang akan dicapai, menetapkan berbagai jenis kegiatan yang harus dilakukan dalam usaha mencapai tujuan yang telah ditetapkan, menetapkan ketentuanketentuan atau norma-norma yang harus ditaati oleh seluruh anggota organisasi sekolah, menetapkan berbagai sarana yang diperlukan dalam usaha mencapai tujuan tersebut, dan menetapkan cara atau metode yang paling baik untuk mencapai tujuan tersebut.

Owens (2010: 151) mengemukakan bahwa faktor-faktor pembentuk komitmen organisasional akan berbeda antara guru baru dan guru yang betugas dalam tahapan lama yang menganggap sekolah atau organisasi tersebut sudah menjadi bagian dalam hidupnya. Komitmen tugas guru pada organisasi sekolah tidak terjadi begitu saja, tetapi melalui proses yang cukup panjang dan bertahap.

Steers dalam Sopiah (2011: 163) mengidentifikasikan ada tiga faktor yang mempengaruhi komitmen guru pada organisasi sekolah, antara lain: 1) ciri pribadi kinerja, termasuk masa jabatannya dalam organisasi sekolah, dan variasi kebutuhan serta keinginan yang berbeda dari tiap guru, 2) ciri petugasan, seperti identitas tugas dan kesempatan berinteraksi dengan rekan sesama guru, 3) pengalaman tugas, seperti keterandalan organisasi di masa lampau dan cara guruguru lain mengutarakan dan membicarakan perasaannya mengenai organisasi sekolah. 
Winardi (2012: 73) mengemukakan empat faktor yang mempengaruhi komitmen tugas guru pada organisasi sekolah, yaitu: a) Faktor personal, misalnya usia, jenis kelamin, tingkat pendidikan, pengalaman tugas, kepribadian, dan lain-lain. b) Karakteristik petugasan, misalnya lingkup jabatan, tantangan dalam petugasan, konflik organisasi, tingkat kesulitan dalam petugasan, dan lain-lain. c) Karakteristik struktur, misalnya besar/kecilnya organisasi sekolah, bentuk organisasi seperti sentralisasi atau desentralisasi, kehadiran serikat guru dan tingkat pengendalian yang dilakukan organisasi sekolah terhadap guru. Menurut Riehl dan Sipple (dalam Solomon, 2007: 13) ada beberapa aspek-aspek komitmen guru adalah belajar dari berbagai sumber ilmu pengetahuan, menjalankan kurikulum dengan tanggung jawab.

\section{Kompetensi Pedagogik Guru}

Sagala mengemukakan sepuluh kompetensi dasar yang harus dimiliki guru, yaitu : (1) menguasai landasanlandasan pendidikan; (2) menguasai bahan pelajaran; (3) kemampuan mengelola program belajar mengajar; (4) kemampuan mengelola kelas; (5) kemampuan mengelola interaksi belajar mengajar; (6) menilai hasil belajar siswa; (7) kemampuan mengenal dan menterjemahkan kurikulum; (8) mengenal fungsi dan program bimbingan dan penyuluhan; (9) memahami prinsip-prinsip dan hasil pengajaran; (10) mengenal dan menyelenggarakan administrasi pendidikan (Sagala, 2006 : 210).

Adapun indikator kompetensi pedagogik antara lain: 1) Pemahaman wawasan atau landasan kependidikan. 2) Pemahaman Terhadap Peserta Didik. 3) Pengembangan Kurikulum/ Silabus. 4) Perancangan Pembelajaran. 5) Pelaksanaan Pembelajaran Yang Mendidik Dan Dialogis. 6) Evaluasi Hasil Belajar. 7) Pengembangan peserta didik untuk mengaktualisasikan potensi yang dimilikinya.

\section{Peran Pengawas Sekolah}

Peran pengawas sekolah diukur berdasarkan: perencanaan supervisi akademik, pelaksanaan supervisi akademik, teknik supervisi akademik, evaluasi hasil supervisi akademik. Menurut Bernardin dan Russel (2013: 379) "A way of measuring the contribution of individuals to their organization". Penilaian kinerja adalah cara mengukur konstribusi individu (karyawan) kepada organisasi tempat mereka betugas.

Menurut Wahyudi (2012: 101) "penilaian kinerja adalah suatu evaluasi yang dilakukan secara periodik dan sistematis tentang prestasi tugas/jabatan seorang tenaga tugas, termasuk potensi pengembangannya"

Aspek yang dinilai pada penilaian kinerja pengawas sekolah mengacu kepada Peraturan Menteri Pendayagunaan Aparatur Negara dan RB Nomor 21 Tahun 2010 yang meliputi: (1) Penyusunan program pengawasan. (2) Pelaksanaan program pengawasan. (3) Evaluasi hasil pelaksanaan program pengawasan. (4) Pembimbingan dan Pelatihan profesional guru dan/ atau kepala sekolah.

\section{Peran Kepala Sekolah}

Peran dan tugas tersebut dikenal dengan EMASLIM sebagai berikut : 1) Kepala sekolah sebagai educator atau pendidik. 2) Kepala sekolah sebagai manajer, kepala sekolah harus memiliki strategi yang mampu mengimplementasikan fungsi-fungsi manajemen dengan efektif dan efisien. Terdapat tiga keterampilan minimal yang perlu dimiliki oleh kepala sekolah sebagai manajer,yaitu keterampilan konseptual, keterampilan kemanusiaan, serta keterampilan teknis. 3) Kepala sekolah sebagai administrator, peran dan tugas kepala sekolah sebagai administrator. 4) Kepala sekolah sebagai supervisor atau pengawas, kemampuan kepala sekolah sebagai seorang supervisor dapat dilihat dari kemampuan program supervisi pendidikan, kemampuan melaksanakan program supervisi pendidikan. 5) Kepala 
sekolah sebagai inovator, sekolah sebagai lembaga pendidikan harus tampil sebagai organisasi pendidikan yang mampu meningkatkan kualitas sumber daya manusia. (Euis dan Donni, 2013: 115 117). 6) Kepala sekolah bertugas mencari dan melakukan pembaharuan dalam berbagai aspek, mendorong guru staf dan orang tua untuk memahami dan memberikan dukungan terhadap pembaharuan yang ditawarkan (Sutomo, 2011: 98).

\section{B. Metode Penelitian}

Penelitian tindakan Sekolah ini dilaksanakan di SMA Negeri 7 Tangerang dari bulan Agustus sampai dengan Oktober 2018. Dalam penelitian ini yang menjadi subyek penelitian adalah guru di SMA Negeri 7 Kota Tangerang dengan jumlah 50 orang. Objek dalam penelitian ini adalah komitmen tugas terhadap kompetensi pedagogik guru SMA Negeri 7 Kota Tangerang.

\section{Siklus Pertama}

Perencanaan yang dilakukan adalah :

1) Sosialisasi PTS. 2) Dalam mengidentifikasi dan merumuskan masalah, peneliti berkolaborasi dengan kepala sekolah dan wakasek Kurikulum. 3)Membuat rencana supervisi kelas. 4) Menyusun jadwal supervisi bersama kepala sekolah. 5) Meyusun instrumen penelitian diantaranya angket komitmen tugas dan lembar pengamatan kompetensi pedagogik guru. 6) Mempersiapkan daftar hadir

Pelaksanaan siklus pertama diantaranya : Menjelaskan kegiatan PTS untuk meningkatkan komitmen tugas terhadap kompetensi pedagogik dengan adanya kegiatan supervisi yang akan dilakukan oleh pengawas, kepala sekolah dibantu oleh wakasek kurikulum.2). Mengadakan pembimbingan proses pembelajaran. 3). Berdiskusi antara peneliti dan guru. 4). Guru mengisi angket komitmen tugas 5). Menarik kesimpulan,

Observasi yang diperoleh peneliti dengan kolaborator berdasarkan angket komitmen tugas serta hasil observasi kompetensi pedagogik guru dianalisis agar diperoleh hasil yang objektif. Hasil diskusi digunakan untuk perencanaan, melaksanakan dan merefleksi pada siklus kedua

Refleksi Setelah pelaksanaan supervisi kelas, peneliti dan observer berdiskusi dan menganalisa apa yang telah dilaksanakan. Dari hasil pengamatan serta pengisian angket kemudian diperoleh kekurangan dan kelebihan sebagai berikut : 1) guru yang kurang memahami proses pembelajaran. 2) Guru yang kurang memahami komitmen tugas. 3). Guru perlu melaksanakan proses pembelajaran yang benar. 4) Guru perlu memiliki komitmen tugas yang baik agar kompetensi pedagogiknya meningkat. Yang selanjutnya dipergunakan sebagai dasar untuk menyusun langkah pada siklus II.

\section{Siklus Kedua}

Perencanaan pada siklus kedua adalah: 1)Dalam mengidentifikasi dan merumuskan masalah, peneliti berkolaborasi dengan kepala sekolah dan wakasek Kurikulum 2) Membuat rencana supervisi kelas untuk siklus kedua 3)Menyiapkan lembar observasi dan angket 4)Menganalisa hasil supervisi pada siklus kedua dengan bantuan observer

Pelaksanaan siklus kedua berdasarkan hasil refleksi siklus pertama diantaranya : 1) Menginformasikan hasil supervisi pada siklus pertama. 2) berdiskusi antara peneliti, observer dan guru. 3). Guru mengisi angket komitmen tugas. 4) Menarik kesimpulan. Hasil yang dicapai oleh peneliti saat pengamatan proses pembelajaran dan angket. Kemudian dianalisis oleh peneliti dan berkolaborasi dengan cara berdiskusi agar diperoleh hasil yang objektif. Proses pembelajaran dikelas sudah benar sesuai dengan standar. Dengan demikian terjadi peningkatan komitmen tugas terhadap kompetensi pedagogik .

Observasi Selama pelaksanaan siklus kedua berlangsung, peneliti dan observer mengamati proses pembelajaran guru. Dari data observasi dan angket dianalisis oleh 
peneliti dan kolaborasi dengan cara berdiskusi dan berkoordinasi. Hasil diskusi digunakan untuk merefleksi pada siklus kedua

Refleksi pada akhir siklus II ini diadakan refleksi berdasarkan data/hasil observasi serta angket oleh peneliti dan kolaborator yang dilakukan dalam penelitian ini. Apabila terjadi peningkatan komitmen tugas terhadap kompetensi pedagogik guru, maka penelitian dapat dihentikan sampai pada siklus II, namun bila penelitian belum mencapai indikator keberhasilan yang telah ditetapkan maka penelitian dilanjutkan pada siklus berikutnya.

Instrumen yang digunakan untuk memperoleh data yang diperlukan dalam penelitian ini terdiri atas observasi, angket dan dokumentasi. Kriteria keberhasilan ditekankan pada peningkatan komitmen tugas terhadap kompetensi pedagogik guru melalui peran pengawas dan kepala sekolah ini adalah : "Penelitian ini dikatakan berhasil jika terjadi peningkatan hasil skor rata-rata komitmen tugas minimal $80 \%$ dengan kategori tinggi dan kompetensi pedagogik minimal $65 \%$ guru rata-rata mencapai kriteria amat baik".

\section{Hasil Penelitian dan Pembahasan Siklus Pertama \\ Perencanaan diantaranya :}

sosialisasi PTS, peneliti berkolaborasi dengan kepala sekolah dan wakasek Kurikulum, membuat rencana supervisi kelas, menyusun jadwal supervisi bersama kepala sekolah, meyusun instrumen penelitian diantaranya angket komitmen tugas dan lembar pengamatan kompetensi pedagogik guru, mempersiapkan daftar hadir

Pelaksanaan siklus I dilakukan dari tanggal 1 sampai dengan 15 September 2018. Sebagaimana yang telah dijadwalkan, pada hari Sabtu, tanggal 1 September 2018 pukul 08.00 sampai dengan pukul 12.00 diadakan sosialisasi kegiatan PTS untuk meningkatkan komitmen tugas terhadap kompetensi pedagogik dengan adanya kegiatan supervisi yang akan dilakukan oleh pengawas, kepala sekolah dibantu oleh wakasek kurikulum sebagai kolaborator. Pengawas mengadakan pengarahan tentang langkah-langkah proses pembelajaran yang benar serta fokus pada komitmen tugas sebagai guru guna meningkatkan kompetensi pedagogik. Peneliti mengadakan diskusi dan tanya jawab bersama guru. Kemudian guru mengisi angket komitmen tugas yang dibagikan oleh pengawas secara jujur. Dari tanggal 3 sampai dengan 14 September 2018 diadakan supervisi kelas sesuai dengan jadwal mengajar oleh peneliti, kepala sekolah dan wakasek kurikulum. Dan pada tanggal 15 September 2018 diadakan pertemuan untuk menarik kesimpulan dari hasil yang dicapai oleh peneliti saat pengamatan proses pembelajaran dan angket.

Hasil observasi diperoleh hasil Penilaian melalui kompetensi pedagogik guru SMA Negeri 7 Kota Tangerang pada siklus pertama, 11 orang atau $22 \%$ guru dengan kriteria amat baik, 32 orang atau $64 \%$ dengan kategori baik dan 7 orang atau $14 \%$ dengan kategori cukup. Hasil angket komitmen tugas pada siklus pertama diantaranya bahwa kategori sangat tinggi hanya 1 orang, kategori tinggi 11 orang, kategori sedang 30 orang dan kategori rendah ada 8 orang dengan rata-rata nilai 74,41 termasuk pada kategori sedang.

Refleksi, masih ada beberapa hal yang perlu diperbaiki, yaitu :1) Kompetensi pedagogik guru yang hanya mencapai nilai rata-rata $65,4 \%$ dengan rincian sebagai berikut : 11 orang atau $22 \%$ guru dengan kriteria amat baik, 32 orang atau $64 \%$ dengan kategori baik dan 7 orang atau $14 \%$ dengan kategori cukup. Minimal pada siklus berikutnya rata-rata nilai kompetensi pedagogik mencapai kategori baik dan memenuhi kriteria indikator keberhasilan yaitu minimal $65 \%$ guru rata-rata mencapai kriteria amat baik. 2) Dari hasil angket komitmen tugas yang 
diberikan kepada guru, menyatakan bahwa kategori sangat tinggi hanya 1 orang, kategori tinggi 11 orang, kategori sedang 30 orang dan kategori rendah ada 8 orang dengan rata-rata nilai 74,41 termasuk pada kategori sedang.

\section{Siklus Kedua}

Perencanaan antaranya : 1)

Peneliti berkolaborasi dengan kepala sekolah dan wakasek Kurikulum. 2) Membuat rencana untuk supervisi kelas untuk perbaikan. 3) Menyiapkan jadwal supervisi. 4) Meyiapkan instrumen penelitian diantaranya angket komitmen tugas dan lembar pengamatan kompetensi pedagogik guru. 5) Menyiapkan daftar hadir

Pelaksanaan siklus kedua hampir sama dengan siklus pertama dan berdasarkan refleksi siklus pertama. Pelaksanaan siklus II dilakukan dari tanggal 17 sampai dengan 29 September 2018. Sebagaimana yang telah dijadwalkan, pada hari Sabtu, tanggal 15 September 2018 pukul 08.00 sampai dengan pukul 12.00 diadakan sosialisasi kegiatan PTS untuk meningkatkan komitmen tugas terhadap kompetensi pedagogik dengan adanya kegiatan supervisi yang akan dilakukan oleh pengawas, kepala sekolah dibantu oleh wakasek kurikulum sebagai kolaborator. Pengawas mengadakan pengarahan kembali tentang langkah-langkah perbaikan proses pembelajaran guna meningkatkan kompetensi pedagogik serta peningkatan komitmen tugas sebagai guru.

Dari tanggal 17 sampai dengan 28

September 2018 diadakan supervisi kelas kembali pada siklus kedua oleh peneliti, kepala sekolah dan wakasek kurikulum. Pada akhir siklus kedua, guru mengisi angket komitmen tugas yang dibagikan oleh pengawas secara jujur. Dan pada tanggal 29 September 2018 diadakan pertemuan untuk menarik kesimpulan dari hasil yang dicapai oleh peneliti saat pengamatan proses pembelajaran dan angket.
Hasil observasi pada siklus kedua, 35 orang atau $70 \%$ guru dengan kriteria amat baik, 15 orang atau $30 \%$ dengan kategori baik dan mencapai nilai rata-rata $73,2 \%$. Dengan demikian kompetensi pedagogik guru sudah meningkat dan sesuai dengan yang diharapkan dalam penelitian tindakan sekolah ini. Hasil angket komitmen tugas pada siklus kedua diantaranya bahwa kategori sangat tinggi ada 8 orang, kategori tinggi 25 orang, kategori sedang 14 orang dan kategori rendah hanya ada 3 orang dengan rata-rata nilai 81,93 termasuk pada kategori tinggi.

Refleksi, berdasarkan hasil observasi pelaksanaan pada siklus kedua, diantaranya kompetensi pedagogik guru yang sudah mencapai nilai rata-rata 73,2 \% dengan rincian sebagai berikut : 35 orang atau $70 \%$ guru dengan kriteria amat baik, 15 orang atau $30 \%$ dengan kategori baik. Dengan demikian kompetensi pedagogik guru sudah meningkat dan sesuai dengan yang diharapkan dalam penelitian tindakan sekolah ini dengan indikator keberhasilan yaitu minimal $65 \%$ guru rata-rata mencapai kriteria amat baik. Sedangkan dari hasil angket komitmen tugas yang diberikan kepada guru, menyatakan bahwa kategori sangat tinggi ada 8 orang, kategori tinggi 25 orang, kategori sedang 14 orang dan kategori rendah hanya ada 3 orang dengan rata-rata nilai 81,93 termasuk pada kategori tinggi. Dengan demikian berdasarkan hasil penelitian tindakan sekolah sudah mencapai indikator keberhasilan, maka penelitian dihentikan sampai pada siklus kedua saja.

\section{Pembahasan}

Hasil observasi terhadap tindakan perbaikan siklus pertama dengan menggunakan intrumen penilaian kompetensi pedagogik guru yang hanya mencapai nilai rata-rata 65,4\% dengan 11 orang atau $22 \%$ guru dengan kriteria amat baik, 32 orang atau $64 \%$ dengan kategori baik dan 7 orang atau $14 \%$ dengan kategori cukup. Sedangkan dari hasil angket komitmen tugas yang diberikan kepada guru, menyatakan bahwa 
kategori sangat tinggi hanya 1 orang, kategori tinggi 11 orang, kategori sedang 30 orang dan kategori rendah ada 8 orang dengan rata-rata nilai 74,41 termasuk pada kategori sedang.

Sedangkan pada siklus kedua, berdasarkan hasil observasi, diantaranya kompetensi pedagogik guru yang sudah mencapai nilai rata-rata $73,2 \%$ dengan 35 orang atau $70 \%$ guru dengan kriteria amat baik, 15 orang atau $30 \%$ dengan kategori baik. Dan berdasarkan dari hasil angket komitmen tugas yang diberikan kepada guru, menyatakan bahwa kategori sangat tinggi ada 8 orang, kategori tinggi 25 orang, kategori sedang 14 orang dan kategori rendah hanya ada 3 orang dengan rata-rata nilai 81,93 termasuk pada kategori tinggi.

Di SMA Negeri 7 Kota Tangerang selalu mengedepankan kedisiplinan baik itu untuk siswa maupun gurunya. Kedisiplinan itu dimulai oleh kepala sekolah. Dari hasil pengamatan pengawas sebagai peneliti, Kepala Sekolah biasanya berangkat lebih awal dan pulang lebih akhir. Karena sikap Kepala Sekolah SMA Negeri 7 Kota Tangerang, guru-guru menjadi rajin dan segan jika datangnya terlambat. Kalau ada guru yang tidak masuk mengajar guru tersebut wajib memberi surat izin beserta alasan yang tepat tidak masuk mengajar dan wajib memberi tugas kepada peserta didik. Jadi meskipun guru tidak hadir siswa tetap bisa melakukan proses pembelajaran sebagaimana mestinya. Kedisiplinan tidak hanya ditujukan pada peserta didik akan tetapi guru juga perlu ditingkatkan kedisiplinannya karena guru sebagai contoh bagi peserta didiknya.

Kepala Sekolah SMA Negeri 7 Kota Tangerang selalu memberikan motivasi agar komitmen tugas guru ditingkatkan, agar kompetensi pedagogik gurupun akan meningkat. Meningkatkan kompetensi profesional guru membutuhkan motivasi dan dukungan dari berbagai pihak, seperti halnya motivasi dari kepala sekolah, untuk lebih kreatif dan inovatif dalam proses pembelajaran di kelas serta disiplin dan komitmen tugas semakin baik dari semua guru guna menghasilkan siswa dengan lulusan terbaik.

Supervisi dilakukan dengan tujuan memberikan layanan dan bantuan untuk meningkatkan kualitas mengajar guru di kelas yang pada gilirannya untuk meningkatkan kualitas belajar siswa, bukan saja memperbaiki kemampuan mengajar tapi juga untuk pengembangan potensi kualitas guru. Sehubungan dengan hal itu, maka kepala sekolah sebagai supervisor hendaknya pandai meneliti, mencari dan menentukan syarat-syarat mana yang diperlukan bagi kemajuan sekolahnya sehingga tujuan pendidikan di sekolah itu tercapai dengan maksimal. Biasanya supervisi yang dilakukan di SMA Negeri 7 Kota Tangerang dilaksanakan 1 kali dalam setahun. Dengan demikian melalui peran pengawas dan kepala sekolah dapat meningkatkan komitmen tugas terhadap kompetensi pedagogik guru. Hal ini berdasarkan pada hasil penilaian kompetensi pedagogik guru dan hasil angket komitmen tugas yang diberikan pada guru.

\section{Kesimpulan dan Saran}

Berdasarkan hasil penelitian, diperoleh kesimpulan sebagai berikut : 1)Terjadi peningkatan komitmen tugas dengan nilai rata-rata 74,41 termasuk pada kategori sedang pada siklus pertama dan pada siklus kedua mencapai nilai rata-rata 81,93 termasuk pada kategori tinggi. 2) Kompetensi pedagogik guru dengan nilai rata-rata $65,4 \%$ yaitu 11 orang atau $22 \%$ guru dengan kriteria amat baik, 32 orang atau $64 \%$ dengan kategori baik dan 7 orang atau $14 \%$ dengan kategori cukup pada siklus pertama dan meningkat pada siklus kedua mencapai nilai rata-rata $73,2 \%$ dengan 35 orang atau $70 \%$ guru dengan kriteria amat baik, 15 orang atau $30 \%$ dengan kategori baik.

Berdasarkan hasil observasi diketahui bahwa guru di SMA Negeri 7 Tangerang masih banyak yang belum aktif 
mengikuti kegiatan MGMP mata pelajaran di tingkat Kota. Oleh karena itu, guru diharapkan dapat melibatkan diri dalam kegiatan MGMP sehingga dapat meningkatkan kompetensi pedagogik guru dalam mengajar di kelas. Kepala sekolah disaankan agar memfasilitasi guru yang jadi bawahannya untuk aktif dalam kegiatan MGMP guna meningkatkan kompetensi pedagogiknya. Kemampuan pedagogik yang meningkat akan berimbas pada peningkatan mutu pendidikan di sekolah.

\section{E. Daftar Pustaka}

Bernardin, H. John and Russel, E.A., 1993. Human resource Management, An Experiential Approach. Mc. Graw Hill International Edition, Singapore: Mac Graw Hill Book Co.

Departemen Pendidikan Nasional. 2005. Peraturan Pemerintah Nomor 19 Tahun 2005 tentang Standar Nasional Pendidikan. Jakarta: Depdiknas.

Departemen Pendidikan Nasional. 2005. Undang-Undang Nomor 14 Tahun 2005,Tentang Guru dan Dosen. Jakarta: Depdiknas.

Depdikbud. 2001. Panduan Manajemen Sekolah. Jakarta Direktorat Dikmenum.

Euis dan Donni. 2014. Manajemen Kelas (Classroom Management) Guru Profesional yang Inspiratif, Kreatif, Menyenangkan, dan Berprestasi. Bandung: Alfabeta.

Fred C. Lunenburg. 2013. Convergent Roles of the School Principal:
Leadership, Managerial, and Curriculum-Instructional.

International Journal of Education. Volume 1. Number 1. Diakses pada tanggal 07 April 2017.

Marselus R. Payong. 2011. Sertifikasi Profesi Guru; Konsep Dasar, Problematika, dan Implementasinya. Jakarta: PT Indeks Permata Puri Media.

Owens, Robert G. 2010. Organizational Behavior in Education. Allyn and Bacon. Boston.

Robbins, Stephen. 2000. Perilaku Organisasi. Klaten: PT. Intan Sejati.

Solomon. 2007. Dimension of Teacher Behavior. Journal of Experimental. Education. Diakses pada tanggal 06 Februari 2017.

Sopiah. 2011. Perilaku Organisasi. Yogyakarta: Andi.

Suharsimi Arikunto. 2004. Dasar-Dasar Evaluasi Pendidikan. Jakarta: Bumi Aksara.

Sutomo. 2011. Manajemen Sekolah. Semarang: Universitas Negeri Semarang Press.

Syaiful Sagala. 2011. Supervisi Pembelajaran. Bandung: Alfabeta.

Wahyudi. 2002. Manajemen Sumber Daya Manusia. Bandung: Sulita.

Winardi. 2012. Manajemen Perilaku Organisasi. Cetakan kedua. Jakarta: Kencana Prenada Media Group.

Wursanto. 2010. Dasar-Dasar Ilmu Organisasi. Yogyakarta: Andi. 